\title{
SEVEN NEW WHITE-WINGED DOVES FROM MEXICO, CENTRAL AMERICA, AND SOUTHWESTERN UNITED STATES
}

\author{
By \\ George B. Saunders \\ Wildlife Biologist, Division of Wildlife Research \\ BUREAU OF SPOR'T FISHERIES AND WILDLIFE
}

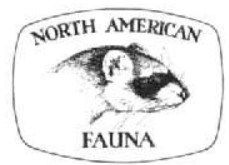

NUMBER 65 


UNITED STATES
DEPARTMENT OF THE INTERIOR
Stewart L. Udall, Secretary
Stanley A. Cain
Assistant Secretary for Fish and Wildlife and Parks
FISH AND WILDLIFE SERVICE
Clarence F. Pautzke, Commissioner
BUREAU OF SPORT FISHERIES AND WILDLIFE
John S. Gottschalk, Director

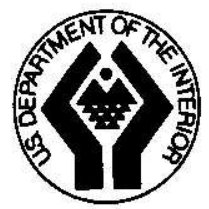

North American Fauna, Number 65

Published by

Bureau of Sport Fisheries and Wildlife

May 1968 


\section{CONTENTS}

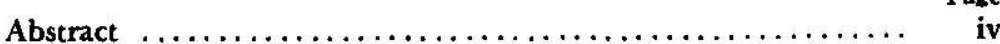

Introduction $\ldots \ldots \ldots \ldots \ldots \ldots \ldots \ldots \ldots \ldots \ldots, 1$

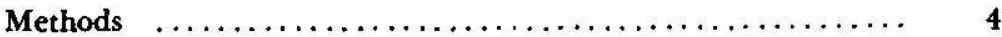

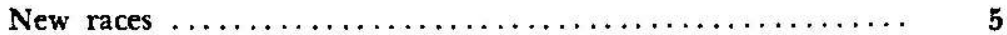

Zenaida asiatica peninsulae $\ldots \ldots \ldots \ldots \ldots \ldots \ldots \ldots \ldots, 5$

Zenaida asiatica grandis $\ldots \ldots \ldots \ldots \ldots \ldots \ldots \ldots \ldots,{ }_{8}$

Zenaida asiatica monticola ....................... 10

Zenaida asiatica palustris ....................... 14

Zenaida asiatica insularis ....................... 15

Zenaida asiatica collina ........................ 17

Zenaida asiatica panamensis ..................... 20

Discussion $\ldots \ldots \ldots \ldots \ldots \ldots \ldots \ldots \ldots \ldots \ldots \ldots \ldots, \quad 21$

Summary $\ldots \ldots \ldots \ldots \ldots \ldots \ldots \ldots \ldots \ldots \ldots \ldots \ldots \ldots, \quad 28$

Literature cited $\ldots \ldots \ldots \ldots \ldots \ldots \ldots \ldots \ldots \ldots \ldots \ldots, \quad 29$

TABLE-Measurements of 12 subspecies of white-winged doves . 22

Figures

1. Map of breeding ranges $\ldots \ldots \ldots \ldots \ldots \ldots \ldots \ldots \ldots \ldots \ldots, 24$

2. Statistical comparison of wing measurements ........... 25

3. Statistical comparison of tail measurements $\ldots \ldots \ldots \ldots \ldots .26$

4. Statistical comparison of culmen measurements ........ 27 Approved for publication, January 4, 1968. 


\section{ABSTRACT}

Seven new subspecies of Zenaida asiatica are described: Z. a. peninsulae of the Yucatán Peninsula, México; Z. a. grandis of the upper Big Bend area, central western Texas; Z. a. monticola chiefly of the Mexican interior plateaus and highlands; $Z$. a. palustris of the central and southern Pacific coastal plains of México; $Z$. a. insularis of the Tres Marías Islands, Nayarit, México; Z. a. collina of Central America, chiefly on the Pacific Piedmont and coastal plain from the Isthmus of Tehuantepec, México to Costa Rica; and Z. a. panamensis of the northeast coast of the Azuero Peninsula, Panamá. 


\section{INTRODUCTION}

Of the white-winged dove, Zenaida asiatica, five subspecies have been generally recognized by taxonomists: Z. a. asiatica, Z. a. mearnsi, Z. a. australis, $Z$. a. meloda, and $Z$. a. alticola. Ranges of the races asiatica and mearnsi extend as far north as the southwestern United States, australis is in some of the lowlands of Central America, and meloda is in western South America (Peters, 1937, p. 87-88; Hellmayr and Conover, 1942, p. 499-503). Later the race alticola was described from the Altos, the high mountain region of western Guatemala, and neighboring highlands (Saunders, 1951).

Van Rossem (1947) described a subspecies clara from the Cape region of Baja California, pointing out that it was paler than mearnsi, but clara was not generally accepted (Friedmann et al., 1950). The series of 23 males and 14 females from Baja California examined during the present study do not show sufficient differences from mearnsi to justify separation from that race. The peninsular birds have longer wings and tail than mearnsi, but in adult males these differences are only 2 millimeters in average length of wings and 3 millimeters in average length of tail. The Baja California whitewings seem to be relatively sedentary-apparently they do not migrate beyond that State. Additional research may reveal other differences from mearnsi in habits and ecology.

The present paper describes seven new subspecies. Apparently, ornithologists have assumed that asiatica is the resident form in much of Central America because their collections, made mostly in the autumn and winter months, include so many of this race; other whitewings have been lumped as asiatica with the observation that this race shows wide variation (Dickey and van Rossem, 1938; Griscom, 1932; and Ridgway, 1916). While many asiatica winter as far south as Costa Rica, they do not breed in Central America (Saunders, 1959, 1962). It now appears that the race asiatica is much less variable in color and size than was formerly believed.

My interest in this problem began in 1940 when some of the whitewing nestlings we banded in southern Texas in summer were reported during autumn and winter in Guatemala and El Salvador. In 1942 I visited these countries for the first time during winter and spring to study the numbers and distribution of these doves and the factors affecting them.

It was during this survey that alticala was found in the Altos of Guatemala (Saunders, 1951), and other series of whitewings were collected in different parts of Guatemala and El Salvador. Further collecting was done there in 1946 and 1947, and in México from 
1940 through 1960. Other specimens were borrowed from the principal museums and from several universities and individuals. When the breeding specimens were sorted out and their distribution studied, there appeared to be several undescribed races. A statistical analysis of the measurements of specimens was made to determine whether this method would substantiate the presence of new subspecies.

It is very significant that more than $450 \mathrm{Z}$. a. asiatica banded in Texas have been reported from localities in Latin America south of their breeding places and on wintering grounds as far away as Costa Rica. More than 250 banded Z. a. mearnsi from Arizona have been reported from western México. The patterns of these recoveries are an invaluable aid to understanding racial distribution of this species.

The extent of migration of the races that breed in Central America is not yet adequately known. Some subspecies appear to be mostly sedentary, such as alticola in the Altos of Guatemala (Saunders, 1951). Skutch (1964, p. 224) reported that they nested in March and April in the Sierra de Tecpán, Guatemala, up to 9,000 feet above sea level, but after the rainy season began in mid-May they disappeared until late in the following November. This indicates that in part of their range there is a seasonal movement, perhaps mostly altitudinal. But we lack specimens of this race to show its distribution south of Guatemala.

Members of the Bureau of Sport Fisheries and Wildlife to whom I am especially indebted include John W. Aldrich for advice on taxonomic questions, Ralph Andrews for field assistance on our Mexican survey in 1960, Richard C. Banks for advice on taxonomy, Earl Baysinger for tabulations of banding and recoveries, Thomas D. Burleigh, formerly with the Bureau and now retired, for skins for study, Allen Duvall for suggestions in studies of banding, Aelred D. Geis and Robert G. Heath for statistical assistance, Mary W. Mann, artist, Bird and Mammal Laboratories, for the distribution map and figures, and Lester L. Short, Jr., formerly with the Bureau and now with the American Museum of Natural History, for help with taxonomic questions.

On the surveys in Guatemala in 1947, Charles O. Handley, Jr., U. S. National Museum, aided in obtaining specimens, as did Clarence Cottam, Director, Welder Wildlife Foundation, on the 1957 survey in México.

I also wish to thank the following institutions and individuals for lending specimens essential for this study and for assistance when I visited and studied some of the collections: Academy of Natural Sciences of Philadelphia (R. M. deSchauensee and James Bond); American Museum of Natural History (Dean Amadon); British Museum (J. D. MacDonald); Carnegie Museum (Arthur C. Twomey and Kenneth C. Parkes); Field Museum of Natural History (E. R. Blake and the late Boardman Conover); Colorado Museum of Natural History (Alfred M. Bailey and Robert Niedrach); Louisiana State 
University, Museum of Zoology (George H. Lowery, Jr., and Robert Newman); Texas A. \& M. University, Department of Wildlife Management (W. B. Davis); U. S. National Museum (Philip S. Humphrey); University of California, Berkeley, Museum of Vertebrate Zoology (the late Alden H. Miller); University of California, Los Angeles (the late A. J. van Rossem); University of Florida, Department of Zoology (Pierce Brodkorb); University of Kansas, Museum of Natural History (Richard F. Johnston) ; and University of Michigan, Museum of Zoology (R. W. Storer and the late J. Van Tyne).

Others to whom I am grateful for specimens or information are Rollin H. Baker, Michigan State University; Alvaro Collado M., San José, Costa Rica; Robert W. Dickerman, then with the Oficina San. itaria Pan Americana, México, D. F., and now with the Cornell University Medical College, New York, N. Y.; Herbert Friedmann, then Curator of Birds, U. S. National Museum, and now Director, Los Angeles County Museum; Roland W. Hawkins, Pittsburgh, Pa.; Hugh C. Land, Northwestern State College, Natchitoches, La.; D. B. Legters, Mérida, Yucatán; the late Luis Macias A., Chief, Department of Game, México, D. F.: Burt L. Monroe, Jr., University of Louisville; Allan R. Phillips, Instituto de Biologia, Universidad Nacional Autónoma de México, D. F.; Albert Schwartz, Miami, Fla.; Gilbert Shaw and William Stone, U.S.D.A., Laboratorio Entomilógico, México, D. F.; Alexander F. Skutch, San Isidro del General, Costa Rica; Austin P. Smith, Zarcero, Costa Rica; and Helmuth Wagner, Ubersee Museum, Bremen, West Germany.

Several ornithologists and other scientists now deceased gave me helpful information or other assistance in earlier years: Lee Arnold and Frederick C. Lincoln, Bureau of Sport Fisheries \& Wildlife; Wilfred H. Osgood and Karl P. Schmidt, Field Museum of Natural History; James L. Peters, Museum of Comparative Zoology; Charles Plummer, U. S. Department of Agriculture, México, D.F.; and John T. Zimmer, American Museum of Nautral History. My thanks go also to my fellow biologists and other field men of the States of Arizona and Texas, who have banded many thousands of whitewinged doves since 1940 to obtain information on migration, mortality, and other important subjects. Without so many band recoveries of asiatica and mearnsi to help in clarifying the distribution of these birds in migration and on the wintering grounds in Latin America, the relationships of several races would continue to be much more puzzling.

To Alexander Wetmore I am much indebted for his advice on taxonomic and distributional problems, for his generosity in giving me access to field journals of his 1948 and 1963 collecting trips in Panamá, and for the privilege of describing the subspecies panamensis.

To my wife, Dorothy Chapman Saunders, I owe the principal acknowledgment for her assistance in collecting and preparing specimens, making color comparisons, statistical calculations, and editorial suggestions. 


\section{METHODS}

Since differences in coloration, especially of females, are often subtle, some of the races can generally be separated most accurately on the basis of body size and dimensions. Differences in ecology, time of breeding, and extent of migration also help in characterizing some subspecies.

When field observations and study of laboratory skins suggested differences in a particular population, a statistical analysis was made to determine the possible significance of morphological differences. Mayr considers the conventional level of subspecies difference to be 90 percent or more (Mayr, Linsley, and Usinger, 1953). The criterion used here in determining the validity of races was whether 95 percent or more of the specimens of a population were separable from 95 percent or more of the specimens of the adjacent race or races. To determine the degree of difference and the percentage of joint nonoverlap between characters of races, the standard error was calculated for each mean. Confidence limits were determined for the .05 probability level as the mean \pm " $t$ " times the standard error. The means, confidence limits, and ranges are given in the table and in figures 2 to 4 . When the confidence limits do not overlap, statistically significant differences are indicated.

In this review, 463 adult specimens and several juveniles were studied. They represent most of the known populations from Arizona and Texas south to Ecuador and Peru. The largest series were those of the Fish and Wildlife Service collection in the U. S. National Museum that $I$ had obtained in México and Central America. Specimens from the West Indies were not included. Birds from Jamaica, Cuba, Haiti, Dominican Republic, the Bahamas, and Old Providence Island were examined, but additional breeding specimens are needed before some puzzling questions can be answered and an adequate appraisal made of their taxonomy. The specimens of asiatica included in the present tabulation of measurements were from breeding grounds in southern Texas and northeastern México.

Measurements used in this study include length of wing (chord), taii, culmer, and tarsus, although the tarsus is not included in most of the comparisons as it is not of significant diagnostic value. Statistical differences in dimensions are shown in the table and in figures 2 to 4 (see pages 22-27). Plumage colors were studied under natural light in most instances. A few were determined under special lights which approximate daylight in the Bird Division, U.S. Museum of Natural History. Color names are from Ridgway (1912).

Since migrant subspecies isay mingle with resident birds during the winter, it is essential that full information, particularly condition of gonads and amount of fat, be recorded in the field. In México and Central America it was usually possible, from February to April, to separate the resident and migrant forms by the greater development 
of the gonads and the much smaller amount of fat in the residents.

In the following comparisons of specimens, males are referred to unless females are specified. In general, males show more racial differences in dimensions, as well as color, than do females, and consequently are of greater value for taxonomic study.

In the original determination of taxonomic differences in any migratory animal it is essential to use specimens that are representative of breeding populations. It would be desirable to have more specimens in fresh plumage for comparison, but by the time the postnuptial molt is completed, considerable migration away from the breeding ground may have occurred, and specimens taken together at that time may represent two or more subspecies. Therefore, the descriptions of these seven new races are based on specimens in breeding condition, with due consideration of adventitious effects of wear and fading. In contrast, the type specimen of australis, taken at Cerro Santa María, Costa Rica, January 9, 1908, (Peters, 1913) is in fine, fresh plumage, so it is not directly comparable with specimens in breeding plumage. It should be noted that no breeding white-winged doves have been reported from that locality. This is an example of doubtful situations which can arise from using wintering or freshly molted specimens in original descriptions.

\section{NEW RACES}

The series of white-winged doves from the Mexican States of Yucatán, Campeche, and Quintana Roo examined in this study exhibits considerable variation. It includes some wintering birds with dimensions and coloration of typical asiatica and others that were smaller and mostly paler. Fifteen of these birds which were collected by Gaumer have no date, and many of them have no locality other than "Yucatán." However, the general season during which they were obtained could be determined by molt and wear of the plumage. When the specimens were sorted according to season, it was found that almost all of those in worn breeding plumage had shorter wings and tails than typical specimens of asiatica in comparable plumage. Field study and this review of specimens have shown that the breeding population of the above area is a distinct subspecies which may be called:

\section{Zenaida asiatica peninsulae, new subspecies Yucatán White-winged Dove}

\section{CHARACTERS}

Nearest to $Z$. a. asiatica but with shorter wings and tail. In breeding plumage the back averages slightly paler and grayer than that of most specimens of asiatica seen. The crown of the male is paler and a lighter purple, and in some specimens is more suffused with 
brown than in asiatica. The latter has more extensive purple that extends farther back on the hindneck. In most of the specimens of peninsulae seen the underparts are slightly paler, and some have a cinnamon tone to the throat and upper breast that occurs in relatively few asiatica.

\section{DESCRIPTION}

Type, Field Mus. Nat. Hist. No. 13223, adult male, San Felipe, near the mouth of the Río Lagartos, northeastern Yucatán, collected June 6,1893 , by W. W. Brown. Crown and hindneck vinaceous drab; back drab; tertiaries buffy brown; middle rectrices olive brown; throat wood brown basally with cinnamon tips; breast light drab; abdomen pearl gray; and flanks pale olive gray.

\section{MEASUREMENTS}

Males (14 specimens): wing $148.5-156.3 \mathrm{~mm}$. (av. 151.5), tail 97.1-108.0 (103.5), and culmen 18.0-21.3 (20.2). Females (18 specimens) : wing 143.0-155.0 mm. (av. 148.6), tail 93.0-104.0 (99.6), and culmen 18.4-21.7 (20.0). Most of these specimens were taken during the breeding season.

Ridgway (1916, p. 379) gave the average measurements of wing, tail, and culmen of 9 males from Yucatán as 156.4, 103.6, and $19.7 \mathrm{~mm}$., and of 7 females as 149.6, 99.4, and $20.2 \mathrm{~mm}$. Judging from the large average wing length there was no sorting of these specimens according to season, and apparently several wintering asiatica males were included.

\section{RANGE}

The only breeding specimens seen were from areas of México including the northern half of Yucatán, coastal localities in Quintana Roo, the adjacent islands of Cozumel and Mujeres, and northern Campeche. A specimen from Jaina, Campeche, taken on June 15, 1900, by Nelson and Goldman, is referable to this form. The only breeder taken by Paynter $(1955$, p. 118) was a male collected at Vigia Chico, Quintana Roo, March 30,1949. That locality is adjacent to Bahía de la Ascensión. Additional specimens from southern Yucatán and Quintana Roo are needed for clarification of the extent of the breeding range.

Based on the relative scarcity of this race in northern Yucatán during the winter, I believe that most of these birds winter farther south in the State, and possibly also in arid interior valleys of eastern Guatemala and Honduras. If so, peninsulae would be associated in some localities with a subspecies to be described further on, as well as with australis.

\section{REMARKS}

The white-winged dove was listed for Mujeres and Cozumel Islands, and was considered a well-known species on the mainland by Salvin 
(1889). Cole (1906) was at Chichén Itzá in March 1904 and collected three specimens March 10-12.

Paynter (1955, p. 118) reported the habitat to be chiefly in coastal scrub and deciduous forest, but occasionally in clearings within the rain forest zone.

Peters (1913, p. 372) took two females on March 16 and 17, 1912, at Camp Mengel, on the Río Hondo, 36 miles southwest of Chetumal, Quintana Roo. I examined one of these specimens, MCZ No. 60754; it is a small bird, typical of peninsulae. Its rectrices are narrow, and its measurements are wing 145.0, tail 96.0, tarsus 22.5, and culmen $18.5 \mathrm{~mm}$.

D. B. Legters, Mérida, who lived and hunted in Yucatán for many years, wrote me in 1961 that he found great numbers of white-winged doves on the northern coast of Yucatán between D7ilam and Telchac in April, May, and June, nesting among the coconut palms and mangroves. A very few remained through the year, mostly in the coconut groves. Chapman (1896) found whitewings in large numbers in the old cornfields near Chichén Itzá in March.

Dr. Allan R. Phillips wrote me in 1965 that he saw no whitewings in México on Isla Mujeres, January 15-18, only one on Isla Cozumel, January 19-23, and very few anywhere in Yucatán, or on the peninsula north or east of Isla del Carmen, where they should have been common. He found none on the Isla Cozumel during extensive daily field collecting, November 3-18, 1965.

During my field work in northwestern Yucatán in January 1960, the only white-winged doves seen or heard were several in the dry woodland south of Umán near the aguada (watering place) Xcamal, and one near the boundary with Campeche, a few miles north of Bolonchén de Rejón, both localities on the Mérida-Campeche highway.

Indians who live near the aguada Xcamal and who had learned a good deal about the "zac pakal," as the Mayas call this dove, said that they were more common during the nesting season, which begins in late March and extends through May, and that few were present the rest of the year. They added that nests were found in densely foliaged, thorny trees near the aguada, some of them placed quite low, and that only one brood was raised. I heard two sing briefly, and their songs were weaker in volume than typical asiatica. When flushed they flew low through the trees, more in the manner of white-fronted doves, rather than above the trees as whitewings usually do.

Three were collected and 20 seen at a watering place 16 miles east of the city of Campeche on January 31, 1960. One specimen was an adult male, the second an adult female, and the third an immature female with two juvenal primaries; all were peninsulae. Two birds there sang in the same low volume that characterized those noted at the aguada Xcamal. Two specimens from San José Carpizo, Campeche 
(Storer, 1961), approximately 27 miles south of the capital, are immature females taken November 1 and 24, 1946. They are probably peninsulae, judging from their measurements.

A juvenile male of peninsulae less than 5 weeks old was collected at Santa Clara, Yucatán, September 2, 1950 (Yale U. No. 14384). It differs from juveniles of asiatica in having conspicuous buffy edging on many of the lesser coverts. The color of the underparts is slightly grayer, and the tips of the breast feathers are more tawny than in asiatica.

Additional proof that asiatica from the north occurs on the Peninsula in winter is found in two white-winged doves banded in Tamaulipas during the breeding season which were shot during winter in Tabasco and Campeche, and two banded in southern Texas which were recovered in Yucatán and Campeche.

\section{SPECIMENS EXAMINED}

México: Yucatán: Izamal, Santa Clara, Chichén Itzá, Sisal, San Felipe, and Xocempich. Some of those collected by Gaumer in Yucatán were not marked as to sex, locality, and date. CAMPECHE: Isla del Carmen near Puerto Real, Jaina, Champotón, and 16 miles east of the city of Campeche. Quintana Roo: Vigía Chico, Camp Mengel, Chetumal, and Isla Cozumel.

Field investigations in the Big Bend sector of Texas and the review of specimens collected there and elsewhere in the Southwest and in México proved that the white-winged dove of the Chinati Mountains and the adjacent valley of the Rio Grande in the upper Big Bend region of Texas is a distinct geographic race. As it is larger than the other known North American species, it is named:

\section{Zenaida asiatica grandis, new subspecies Upper Big Bend White-winged Dove}

\section{CHARACTERS}

It has longer wings, tail, and tarsus than mearnsi, monticola, and asiatica, but its culmen is shorter than that of mearnsi. It is grayer above and paler on the breast than asiatica, and slightly grayer than most mearnsi. The few specimens seen of monticola from the Chisos Mountains and northern México average very slightly browner on the back than grandis, with the purple crown of the male slightly less bright and more veiled with brown. The underparts are somewhat paler in grandis than in asiatica. It is similar to $Z$. a. meloda of South America in length of wing, tail, tarsus, and culmen, but it is much browner. The race meloda has a thicker bill, gray instead of white tips to the rectrices, and other differences in color of plumage. 


\section{DESCRIPTION}

Type, U. S. Nat. Mus. (Fish and Wildlife Service Collection) No. 481592, adult male, breeding, active milk glands, near Ruidosa, Presidio County, Texas, altitude about 3,000 feet, May 25, 1957, by George B. Saunders, collector's number 2662.

Crown vinaceous drab; hindneck light purple drab; back and tertiaries drab; middle rectrices nearest olive brown; throat deep olive buff to avellaneous; breast light drab; abdomen pale smoke gray to pale olive gray; and flanks pale mouse gray.

\section{MEASUREMENTS}

Males (10 specimens) : wing $166.0-175.0 \mathrm{~mm}$. (av. 172.0), tail 120.5139.0 (126.6), tarsus $26.0-28.0$ (26.5), culmen 20.0-23.0 (21.5), length (2) 317-340 (332), extent (2) 518-538 (526). Females (5 specimens) : wing $162.0-164.9 \mathrm{~mm}$. (av. 163.5), tail 112.9-121.3 (116.5), tarsus 25.0-26.9 (25.8), culmen 20.7-22.3 (21.5), length (2) 304-306 (305), extent (2) $494-498$ (496).

\section{RANGE}

Breeds in the Chinati Mountains and adjacent parts of the Rio Grande bottomland from near Presidio, Presidio County, north to Indian Hot Springs, Hudspeth County, Texas. It probably also occurs in the Sierra Vieja, as white-winged doves were seen flying to the bottomland near Porvenir from the direction of those mountains.

A few are reported to winter in the Big Bend region of Texas, but the majority journey farther south into México. How far they go at that season is not known, but a specimen taken in February near Presa Calles, Aguascalientes, México, at 7,000 feet, has the characteristics of this race.

\section{REMARKS}

When male specimens from the lower Big Bend (Lajitas, Castolon, Chisos Mountains) are compared with those from the Chinati Mountains and adjacent valley of the Rio Grande, in the upper Big Bend, it is apparent that the latter have significantly longer wings and tail. This is surprising since the two ranges are separated by less than 60 miles. In the collecting done from Chinati north to Porvenir, 9 of 10 males taken in the breeding season were typical grandis and the tenth was intermediate between grandis and monticola. The ecological differences between their habitats are believed to be the principal basis for the separation of the two populations.

Along the Rio Grande Valley the principal physical barriers between these two populations are the Colorado Canyon, 3.1 miles in length, and the Grand Canyon of Santa Elena, 7 miles in length. These are very narrow, deep canyons, with vertical rocky walls rising at each side of the Rio Grande, and no trees or shrubs bordering the river. 
The upland on each side of the canyon walls is barren, with gravelly hills and no cover for whitewings. The only habitat between these two canyons is in small, isolated coves in the river bottom and at the mouths of tributary arroyos or washes where there are scattered clumps of tamarisk (Tamarix), mesquite (Prosopis), and associated trees.

Formerly there was much more nesting habitat in the river bottomland from Presidio to El Paso. From Presidio northward almost all river bottom woodland that was suitable for nesting has been cleared for agricultural crops for a distance of approximately 25 miles, except for an occasional thin fringe near the river. From near Chinati north to Ruidosa and locally beyond as far as Indian Hot Springs there are occasional coves of woodland, chiefly of dense tamarisk and mesquite, that offer nesting cover for whitewings. When this part of the Rio Grande was scouted by plane in 1949 no adequate cover for white-winged doves was seen north of Esperanza to El Paso.

Although most of the specimens of grandis were collected near Ruidosa where the eastern edge of the river bottomland meets the foothills, the doves flew in from the direction of the Chinati Mountains. This range is to the east, and its highest elevation, Chinati Peak, is 7,730 feet. Local hunters said the whitewings nested in the oak woodland of the mountains. How many grandis nest in the oak woodland of the Chinati Mountains and how many utilize other plant associations remains to be determined.

\section{SPECIMENS EXAMINED}

United States: Texas (Presidio County): Chinati, Ruidosa, and near Porvenir.

All white-winged doves in the interior highlands of México have been referred to the race mearnsi (Friedmann et al., 1950), but breeding specimens collected there have longer wings and tail, shorter bill, and average slightly grayer plumage than Arizona mearnsi. Birds from the more northern highlands, as in Nayarit and Durango, are slightly darker than those of Oaxaca and Puebla, but they too have longer wings and tail than mearnsi. Study of these highland birds confirms that they are a distinct subspecies which may be named:

\section{Zenaida asiatica monticola, new subspecies Mexican Highland White-winged Dove}

\section{CHARACTERS}

It has shorter wings and tail than grandis. Birds from the highlands of Nayarit, Durango, and more northern States average browner than grandis, but those from Puebla and Oaxaca average slightly 
grayer. It is larger and longer in wing and tail than asiatica and mearnsi, and has a shorter bill than the latter. Similar in dimensions to an undescribed race on the Tres Marias Islands, México, but with paler underparts; similar also to $Z$. a alticola of the highlands of Guatemala (Saunders, 1951) but much paler above and below.

\section{DESCRIPTION}

Type, U. S. Nat. Mus. (Fish and Wildlife Service Collection) No. 481589, adult male, breeding, singing on territory, testes $6 \times 12 \mathrm{~mm}$., 11 miles south of Acatlán, Puebla, México, April 28, 1957, collected by George B. Saunders, collector's number 2648. Crown brownish drab; hindneck light brownish drab; back hair-brown; tertiaries buffy brown; middle rectrices clove brown; throat and breast light drab; abdomen pale smoke gray; and flanks light quaker drab.

\section{MEASUREMENTS}

Males (44 specimens, all seasons): wing $161.3-177.0 \mathrm{~mm}$. (av. 167.2), tail 114.0-127.5 (120.4), and culmen 18.9-22.9 (21.1). Females (22 specimens, all seasons): wing 156.0-171.0 mm. (av. 162.8), tail 111.0-124.4 (116.2), and culmen 19.2-23.0 (21.0) .

\section{RANGE}

Interior plateau and some of the mountains from Oaxaca north of the Isthmus of Tehuantepec, northward in the mesquite and guamachil associations, thorn forest, tropical deciduous forest, and in some localities in oak-pine woodland, to northern Chihuahua, Coahuila, and Nuevo León of México, and the Chisos Mountains and lower Big Bend of central western Texas. Most were observed at elevations of 4,000 to 8,000 feet. They have also been found during summer in Hidalgo County, southwestern New Mexico, where 3 of 15 specimens examined were identified as monticola: 2 were collected in 1892, and 1 in 1933. The other 12 were nearer mearnsi. Northern Chihuahua and the southwestern corner of New Mexico may be a zone of intergradation between these two races, but this is an area where whitewings are scarce and local in distribution.

\section{REMARKS}

Although monticola is widely distributed in the highlands, there are many localities where it is absent. Most were observed in dry woodlands or thorn forest, but some were in agricultural valleys where large guamachiles (Pithecellobium dulce) and mesquites offered nesting cover and food, or in pecan groves of some of the valleys, and villages. A few others were seen in higher oak and pine woodland. In many localities their absence was due to a lack of suitable habitat, but conversely many places with what appeared to be a good habitat lacked whitewings. In field work during 1950, 1952, 1957, and 1960 they were observed in the highlands of every interior 
State of México, and they were collected in Oaxaca, Puebla, Guerrero, Morelos, Jalisco, Michoacán, Nayarit, and Aguascalientes during this study.

This race was breeding in Oaxaca and Puebla during the first week in February, although the altitudes were from 4,000 to 7,000 feet. Also, they were breeding in the mountains of Guerrero and Nayarit in March when mearnsi, still heavy with winter fat, were in flocks there in the foothills, and on the coastal plain of these States.

Most monticola are believed to winter in or near their breeding range. Some at the northern end of the range move south for the winter for an undetermined distance, but there are winter flocks as far north as Coahuila and Durango. No specimens of monticola are known to have been collected from coastal areas or any locality south of the Isthmus of Tehuantepec.

Several individuals of asiatica banded in Texas and Tamaulipas, México, and recovered in the Mexican highlands, chiefly in the States of Morelos and Oaxaca, prove that some asiatica migrate through or winter in the range of monticola. Other winter specimens of asiatica have been collected in these southern highlands. Recoveries in the western highlands, and especially in the States of Michoacán and Jalisco, of many Arizona-banded mearnsi prove that many of this subspecies winter there with the resident monticola. If most of the museum specimens of white-winged doves were obtained in winter, it is not surprising that mearnsi was for so long thought to be the resident subspecies throughout the western highlands.

Peters (1937, p. 87), as well as Hellmayr and Conover (1942, p. 500 ), gave the range of mearnsi as extending southward and eastward in México to Puebla. The present study shows that much of this area is within the range of the new race monticola. Specimens from the southern highlands of México in Guerrero, D. F., Morelos, and San Luis Potosí, considered by Pitelka (1948) to be intermediate between asiatica and mearnsi, included some wintering mearnsi and asiatica, as well as summer and autumn monticola.

Several specimens taken in winter in Oaxaca and Puebla were unusually large, and may represent a different race that breeds in the higher mountains of those States and winters at lower elevations with monticola, or they may be grandis which wintered south of the principal range. The inclusion of their measurements with those of monticola is responsible for the upper limits of the wing and tail measurements of monticola exceeding those of grandis. Further field study of breeding populations in different parts of Oaxaca and Puebla is needed to give information on this subject.

Another interesting discovery concerns a population in the mountainous part of Durango, where dimensions of the sexes are about equal. The several females were sexed and labeled in different years 
by two experienced collectors. They also may represent a separate race, for this characteristic is not true of any other known population of white-winged doves.

The white-winged doves from the interior highlands of Sonora at Tecoripa, Cerro Blanco, Opodepe, and Moctezuma probably are referable to monticola, judging from their dimensions, but inclusion in this race should await further study of specimens and ecology.

Several whitewings and a nest with a single nestling were found in northern Coahuila at Noria de Gilberto, by Walter P. Taylor and Clifford C. Presnall, April 9, 1945 (personal correspondence, 1945). These birds probably were of the race monticola, since it occurs north of this area in Brewster County, Texas (Van Tyne and Sutton, 1937).

The differences in habitats occupied by monticola in the lower Big Bend and by asiatica at the northwestern corner of its breeding range in Val Verde County, Texas, apparently serve as ecological barriers and seem to be effective in maintaining the separateness of these populations. In addition, the three long, narrow canyons of the Rio Grande and the barren hills between the breeding ranges of monticola and asiatica probably also assist in separating these races. Although a strong flier like the white-winged dove could easily fly this distance, no flights have been reported along this route. No specimen of either monticola or grandis has been taken near Del Rio, to my knowledge, nor do I know of a specimen of asiatica reported from the Big Bend.

\section{SPECIMENS EXAMINED}

México: Aguascalientes: Presa Calles. Chinuahua: Meoqui, Río Conchos, Río San Pedro. Coahuila: Las Delicias, Piedra Blanca. Distrito Federal: Pedregal. Durango: La Boquilla, Las Bocas, Río Sestin, San Juan (C. Lerdo). Guerrero: Chilpancingo, Colotlipa, and Iguala. Hidalgo: Zimapán. Jalisco: Autlán, Bolanos, Hacienda La Ven. ta, La Cienega, Santa Cruz, Tizapán el Alto (west of L. Chapala), Villa Corona, Zapotián. Michoacín: Zamora. Morelos: Cuernavaca, Puente de Ixtla, Temilpa. Nayarit: Amatlán de Cañas, Hacienda de Ambas Aguas, and Tepic. OAXACA: Cuilapán (near Oaxaca) and La Compañía (near Ejutla de Crespo). Puebla: Acatlán, Atotonilco, Chila, Huejotzingo, Matamoros, Tecomatlán. SAN Luis Potosi: Hacienda Capulín, Salinas Reg, and Santo Domingo. United States: Texas: Lower Big Bend (Black Gap, Boquillas, Castolon, Lajitas, Pine Canyon, Stillwell Crossing, and Wade Canyon. New Mexico: Guadalupe Canyon and Animas Mountains, Hidalgo County. All seasons are represented by this series. 
Series of white-winged doves were collected in México on March 28-30 near San Blas, Nayarit, and on April 1, 1960, south of Escuinapa, Sinaloa. Study of these specimens, in addition to field observations on their distribution, habitat, and habits, showed clearly that at least two different populations were present. Most of the collecting was done in or near the mangrove swamps, and most of the specimens were of a darker population that was breeding in that habitat. The others seen were in drier upland habitats, were in flocks, were fat, and their gonads were little, if any, enlarged. The latter birds were obviously winter residents or migrants, and were identified as mearnsi. The darker breeding race has not been reported previously, so it is described as:

\section{Zenaida asiatica palustris, new subspecies - San Blas White-winged Dove}

\section{CHARACTERS}

Nearest to Z. a. mearnsi (Ridgway, 1915) in size, but darker than that race, and with a shorter bill. It is darker in coloration and has shorter wings and tail than the Tres Marias Islands population described beyond.

\section{DESCRIPTION}

Type, U. S. Nat. Mus. (Fish and Wildlife Service collection) No. 481591, adult male, breeding, near San Blas, Nayarit, México, March 29, 1960, collected by George B. Saunders, collector's number 2672. Crown and nape between vinaceous drab and dark vinaceous drab; back Prout's brown; tertiaries Saccardo's umber to cinnamon brown; middle rectrices between Prout's brown and mummy brown; breast nearest Saccardo's umber; belly pale ecru drab to smoke gray; and flanks light quaker drab.

Principal differences of diagnostic value are: palustris males average a shorter bill than mearnsi, but differentiation of these races is chiefly on the basis of the darker color of both sexes' of palustris. In comparison with the Tres Marias Islands population described beyond, palustris has a shorter wing and is darker in color.

\section{MEASUREMENTS}

Males (22 specimens, mostly breeding): wing 158.0-169.0 mm. (av. 163.2), tail 109.-123.6 (117.2), culmen 19.0-23.0 (20.7). Females (20 specimens, mostly breeding): wing $153.5-166.0 \mathrm{~mm}$. (av. 159.5), tail 107.0-117.0 (112.2), culmen 19.8-23.0 (21.4) .

\section{RANGE}

The specimens of palustris examined in this study were from the mangrove swamps near San Blas, Nayarit, and northward to near 
Mazatlán, Sinaloa. This race also occurs in some mangrove swamps and adjacent woodlands southeast to localities in Guerrero, but further study of museum collections and additional field work will be needed to determine distribution in more detail. There are several specimens of palustris in museum collections from near Acapulco, Guerrero, and six in my series from there. Two of the latter were taken in the breeding season (February 6 and 11, 1949), and four in August and September, 1965 (from A. R. Phillips collection). Most of the specimens I have seen from Sinaloa, Nayarit, Colima (Schaldach, 1963), and Guerrero were taken in winter and were chiefly migrant and wintering mearnsi.

The northern limit of the range of palustris may extend to about Culiacán, Sinaloa. A male collected at Providencia, 15 miles west of Culiacán, April 11, 1963, by A. R. Phillips, is palustris both in coloration and dimensions, although its back is slightly paler than average. There is little mangrove swamp north of Culiacán, and no specimens of palustris have been seen beyond there.

\section{SPECIMENS EXAMINED}

México: Guerrero: Laguna Coyuca, Laguna Cayaco, and Laguna Tres Palos, all near Acapulco; Ciruelar and Tuncingo. NAyARIT: San Blas and Quimeche River (Río Acaponeta). SinAloa: Escuinapa, Mazatlán, and Providencia ( $\mathrm{La}$ Palma). Most of these were taken during the breeding season.

A review of specimens of white-winged doves from the Tres Marias Islands, Nayarit, México, and comparison of them with series taken on the mainland show that they are a separate race. The name proposed is:

\section{Zenaida asiatica insularis, new subspecies Tres Marias White-winged Dove}

\section{CHARACTERS}

Similar to palustris of the adjoining mainland of Nayarit and Sinaloa, but with paler plumage and longer wings. It likewise has longer wings than mearnsi of Arizona and Sonora, but is slightly darker. It is similar in dimensions to Z. a. monticola of the Mexican highlands, but has darker underparts.

\section{DESCRIPTION}

Type, Acad. Nat. Sci. Phila. No. 150095, adult male, María Madre, Tres Marías Islands, Nayarit, México, July 12, 1941, collected by Dawson Feathers, Fifth George Vanderbilt Expedition. Crown deep brownish drab; hindneck brownish drab; back olive brown; tertiaries Saccardo's umber; middle rectrices sepia; throat wood brown to 
sayal brown; breast wood brown; abdomen pale smoke gray to smoke gray; and flanks light mouse gray to pale mouse gray.

Two specimens collected on Maria Madre, May 7, 1897, by Nelson and Goldman are slightly paler than the type; the back is Saccardo's umber and the breast avellaneous.

\section{MEASUREMENTS}

Males (9 specimens) : wing $163.0-176.0 \mathrm{~mm}$. (av. 170.3), tail 114.0 126.0 (121.4), tarsus 25.0-27.0 (25.7), culmen 19.2-21.0 (20.5). Females (4 specimens) : wing $161.8-165.0 \mathrm{~mm}$. (av. 163.3), tail 108.0 $113.00(110.0)$, tarsus 24.0-26.0 (24.6), culmen 20.0-22.0 (20.6).

\section{RANGE}

The Tres Marías Islands, Nayarit, México, 60-75 miles west of San Blas, Nayarit.

\section{REMARKS}

Nelson (1899) was the first to record this species for the Tres Marias. He found white-winged doves rather common residents on both María Madre and María Magdalena, and a few were seen on Maria Cleofás, breeding in the last half of May. The fact that Grayson did not report this species from the Tres Marias on his trips there in 1865, 1866, and 1867 (Lawrence, 1874) led Nelson (1899) to think that these birds were recent residents on these islands. However, white-winged doves have been overlooked in many other places. They can be very Iocal in distribution, especially under adverse ecological conditions.

McLellan (1927) found these doves fairly common at all places visited in Sinaloa and Nayarit, including María Madre, in the fall of 1925. The collection includes a male and female taken on Maria Madre, October 23, 1925.

The Fifth George Vanderbilt Expedition of the Academy of Natural Sciences of Philadelphia collected a good series including the type of insularis on María Madre from July 10 to 16, 1941 (Bond and de Schauensee, 1944).

Stager (1957) found Zenaida in considerable numbers on all islands of the Tres Marias group, although they were outnumbered by Leptotila and Columbigallina. Zenaida was likewise the least abundant on María Cleofás, but could always be found in the forest margin directly behind the beaches on the eastern side of that island.

Grant (1965), in his taxonomic study of the birds of the Tres Marias, examined a series of 10 male and 5 female white-winged doves from the islands and 9 males and 12 females from a nearby area on the mainland. He concluded that the two groups do not differ sufficiently to warrant taxonomic recognition. He probably reached this conclusion largely because some of his mainland specimens were mearnsi migrants and winter visitants from farther north, 
and not the breeding subspecies of the Nayarit mainland. In discussing the disparity in male bill lengths between some of the mainland and the island birds, Grant correctly diagnosed the reason for this difference when he inferred that it might be due to the presence of migrants in the mainland sample.

The nearest breeding population on the mainland is near San Blas, Nayarit, mostly in or near the mangrove swamps. The 22 adult males I examined from this part of the mainland were breeders I collected mostly in that locality and near Escuinapa, Sinaloa, in April 1960. Their bills average almost $2 \mathrm{~mm}$. shorter than those of mearnsi. In late autumn, winter, and early spring, the population of mearnsi in drier woodlands and fields of this coastal plain and foothills of these States, many of them from Arizona as proved by band recoveries, greatly outnumbers that of palustris, which is much more local in distribution.

A series of 25 specimens from the Mexican mainland of Sinaloa and Nayarit nearest the Tres Marías includes no individuals that have the principal characteristics of insularis. The latter are distinctly different although these islands are only 65 miles offshore, west of San Blas, Nayarit.

\section{SPECIMENS EXAMINED}

México: Nayarit: Tres Marias Islands, Maria Madre.

Field studies in Guatemala in 1942, 1946, and 1947 provided many observations on the biology of white-winged doves there. A series of specimens from the dry woodlands was first recorded as mearnsi (Saunders et al., 1950). Later study showed that these represented a new race whose principal range is in the dry woodland of the Pacific piedmont hills of Central America. This new race may be called:

\section{Zenaida asiatica collina, new subspecies Piedmont White-winged Dove}

\section{CHARACTERS}

Compared with alticola, collina is paler and smaller and has shorter wings and tail. It has shorter wings and tail than monticola. It is slightly larger than australis, averages paler on the underparts, and lacks the cinnamon brown tone to the breast and upperparts which usually characterizes that race. Also, it is grayer on the back and rump, and usually more purple on the crown than australis. Compared with panamensis, collina has longer wings and averages darker on the breast and upperparts. Compared with asiatica, collina is slightly larger, and its wings and tail are longer. Compared with 
mearnsi from Arizona, it averages browner, the wing of the male is longer and the culmen shorter; in the female the tail and culmen are shorter.

\section{DESCRIPTION}

Type, U. S. Nat. Mus. (Fish and Wildlife Service Collection) No. 481590, adult male, breeding, near Progreso, Department of Jutiapa, Guatemala, elevation approximately 3,100 feet, March 13, 1942, collected by George B. Saunders, collector's number 1622. Crown dark vinaceous drab; hindneck vinaceous drab; back olive brown; tertiaries Prout's brown; middle rectrices mummy brown; throat and breast nearest buffy brown; abdomen pale drab gray; and flanks pale quaker drab.

\section{MEASUREMENTS}

Males (52 specimens) : wing $158.0-169.9 \mathrm{~mm}$. (av. 162.6), tail 108.0121.9 (118.0), culmen 17.5-22.0 (20.0). Females (22 specimens) : wing I51.0-165.6 mm. (av. I57.4), tail 103.7-111.0 (107.0), and culmen 18.1-22.1 (20.1).

\section{RANGE}

Southernmost México from southeast of the Isthmus of Tehuantepec (Oaxaca and Chiapas) through Central America to the Guanacaste district of Costa Rica (Carriker, 1910), chiefly on the Pacific slope.

\section{REMARKS}

Field studies and specimens indicate that collina occurs in the dry woodland and thorn forests of the coastal plain foothills and lower mountains of the Pacific slope, and in many of the arid interior valleys, including some in the Caribbean drainage. In some places, as at Punta Piedra, Costa Rica, on the Gulf of Nicoya, collina breeds locally in the coastal lowlands. It is not known whether it also nests in mangrove swamps there.

In some localities on the Pacific slope of Guatemala and El Salvador during winter months every white-winged dove I collected was asiatica; in other places they were in equal numbers with collina, and in yet other habitats only a few miles away I found only collina. In some instances collina was the only race present in the thorn forest, and asiatica was often more common in valleys that had extensive weed fields and farms with grain.

One specimen of collina, labeled Panama, is probably from Guatemala. Ridgway (1916, p. 380) wrote, "There is a specimen in the collection of the Carnegie Museum labeled Natá, Coclé, Panama (no. 20777; : Heyde and Lux, collectors); but this is evidently referable to the larger and grayer form from western Mexico, and if really from 
Panama must have been a cage bird; indeed its appearance suggests its having been kept in confinement." This adult male has its primaries and rectrices moderately worn, but no more so than many other breeding white-winged doves. Nothing about the appearance of this specimen indicates that it had been caged; its plumage is not soiled, nor are feathers broken or fault-barred. The date, May 20, 1889, was within the breeding season. It is comparable in size and color to specimens of collina from the Pacific coast and piedmont from Guatemala to Costa Rica. According to Alexander Wetmore, with whom this specimen was discussed, the collectors Heyde and Lux obtained a large number of "trade skins," many of them from Guatemala. There are several instances in which Guatemalan birds in their collections were mislabeled "Panama." For the present it seems inadvisable to accept this specimen as proof that collina occurs there. Collina breeds and winters as far south as the Guanacaste region of Costa Rica, so a few of them may have populated arid woodlands of southwestern Panamá, but if so it is strange that no specimens of this race have been collected or reported there since 1889 .

\section{SPECIMENS EXAMINED}

México: OAXaca: La Ventosa; Chiapas: Berriozabal, Chicomuselo, Cd. Cuauhtemoc, Entronque Santa Isabel, Esperanza, Hacienda Monserrate, Mazapa, Pinuela, Rezo de Oro, San Bartolo, San José (near Comitán), Tuxtla Gutiérrez. Guatemala: Antigua, Chanquejelve, Chiquimula, El Rancho, Lake Atescatempa, Progreso, Sacapulas, San José de Arada, Usumatlán, Zacapa. El Salvador: Laguna de las Ranas, Puerto El Triunfo, Río Goascorán, Río Lempa (near Puente Cuscatlán), San Miguel, Sonsonate. Honduras: Comayagua, Coyoles, El Hatillo, La Hor Archaga, Monte Redondo, Río Hondo, Siguatepeque, Subirana. Nicaragua: Calabasas, San Rafael del Norte. Costa Rica: Hacienda El Pelón, Las Cañas, La Palma de Nicoya, Miravalles, Punta Piedra, Tenorio. All seasons are represented by these specimens, but the majority are of spring and winter months.

Only 11 specimens of white-winged doves from Panamá were available for this study. A twelfth specimen was not sufficiently authenticated to be considered a satisfactory record. The 11 birds were from the coastal mangrove swamps of southwestern Panamá, and eight of the nine males were collected during the breeding season. They are different from other resident populations farther north in Central America and are described as a distinct subspecies which may be called: 


\section{Zenaida asiatica panamensts, new subspecies Panamanian White-winged Dove}

\section{CHARACTERS}

Smaller than collina, especially in wing and tail length, and averaging paler brown on the back and breast. Its undertail coverts are paler than those of collina which average darker gray. It lacks the rich cinnamon brown tones of the back and breast characteristic of most specimens of australis.

\section{DESCRIPTION}

Type, U. S. Nat. Mus. No. 476630, adult male, breeding, Rio Pocrí, Puerto Aguadulce, Coclé, Panamá, March 12, 1962, collected by A. Wetmore. Crown dark vinaceous drab; hindneck vinaceous drab; back and tertiaries buffy brown; middle rectrices mummy brown; throat slightly paler than sayal brown; breast drab; abdomen pearl gray; and flanks pale quaker drab.

Several of the males from Aguadulce are slightly paler on the breast and upper parts than the type specimen. Five of the eight have the middle pair of rectrices marked with a more or less visible terminal band of grayer or paler brown.

The female, No. 477593 , is slightly paler and less vinaceous brown on the breast, and slightly grayer brown on the upper parts. Her crown and nape are a paler vinaceous drab than those of the males.

Compared with collina, most specimens of panamensis are paler and grayer, especially on the back and tertiaries; the chin is grayer and less brownish; the middle rectrices are lighter brown or grayer and often show a paler terminal bar, whereas in collina they are usually more uniformly brown.

Z. a. australis is darker, with a cinnamon brown tone to the breast, and this color usually extends farther down on the under parts than in panamensis, The back, scapulars, tertiaries, wing coverts, and middle rectrices are a darker brown in australis, and its middle rectrices usually are uniformly colored and lack the paler terminal band so common in panamensis. Both male and female panamensis have significantly shorter wings than collina and australis.

\section{MEASUREMENTS}

Males (9 specimens) : wing $150.0-158.0 \mathrm{~mm}$. (av. 154.8), tail 106.5114.0 (110.3), tarsus 23.5-26.0 (24.7), and culmen 19.0-20.5 (19.8). Females (2 specimens) : wing 150.0-151.5 mm. (av. 150.8), tail 104.0105.0 (104.5), tarsus 23.8-24.0 (23.0), and culmen 20.0.

\section{RANGE}

Resident and fairly common in the mangrove swamps around the shores of the Gulf of Parita on the northeastern coast of the Azuero Peninsula, from the lower Rio Parita (Monagrillo), Herrera, to the 
Río Pocri and the Río Antón, Coclé. This race is believed to be nonmigratory.

The breeding habitat in the mangrove swamp woodland apparently is characteristic of this race. None of these birds was observed in other habitat types in the localities visited.

\section{SPECIMENS EXAMINED}

Panamá: La Isleta and Río Pocrí in Aquadulce, Province of Coclé; and Rio Parita in Monagrillo, Province of Herrera.

\section{DISCUSSION}

Of the 12 subspecies mentioned, their grouping in the following table, map, and figures is based on their breeding distribution in three zones, (1) the Gulf and Caribbean, (2) the interior highlands, and (3) the Pacific Coast. Within these groups the arrangement is from north to south. Those of group 1 breed in lowlands of the eastern coast of México and Central America and in the West Indies, and include asiatica, peninsulae, and australis. They are of medium to small sizes for this species, have shorter wings and tail, and live chiefly in tropical and subtropical lowlands.

Group 2 of the interior highlands includes grandis, monticola, and alticola. They are large for whitewings, have longer wings and tail, and do not occur in lowland localities.

Group 3, Pacific Coast, includes mearnsi, palustris, insularis, collina, panamensis, and meloda. The races in this last group are of medium to large size, and the ranges of several extend from the lowlands inland to higher elevations. Their wings and tail are of medium length to long except in the mangrove-dwelling race panamensis, in which these dimensions are smaller.

Figure 1 shows the tentative boundaries of the breeding ranges of the various subspecies, but further information will undoubtedly result in many changes in this map. In the case of australis, for example, the breeding range is without doubt more extensive than shown, but in the series of birds examined, only the localities in northern Honduras were represented by breeding specimens. Their wintering ranges are not mapped because the overlapping of asiatica and mearnsi on the ranges of resident races is so complex. In some places three different races may be wintering in the same locality.

There are many unanswered questions in white-winged dove taxonomy and distribution, especially in areas where insufficient field work and collecting have been done. To determine the ecological distribution of distinct populations, additional specimens should be taken during the breeding season from México south to Costa Rica. Likewise, there are considerable gaps in our knowledge of the distribution and taxonomy of this species in South America and the West Indies. 
TABLE.-Measurements of 12 subspecies of white-winged doves [In millimeters]

\begin{tabular}{|c|c|c|c|c|c|}
\hline $\begin{array}{l}\text { Subspecies } \\
\text { and sex }\end{array}$ & $\begin{array}{l}\text { Number } \\
\text { in sample }\end{array}$ & Range & $\begin{array}{l}\text { Standard } \\
\text { deviation }\end{array}$ & $\begin{array}{l}\text { Standard } \\
\text { error }\end{array}$ & $\begin{array}{l}\text { Mean } \pm \text { Con } \\
\text { dence limits . }\end{array}$ \\
\hline \multicolumn{6}{|l|}{ Wing measurements: } \\
\hline \multicolumn{6}{|l|}{ asiatica: } \\
\hline males $\ldots \ldots \ldots \ldots$ & 32 & $151.0-164.0$ & 2.93 & 0.52 & $157.3 \pm 1.1$ \\
\hline \multicolumn{6}{|l|}{ peninsulae: } \\
\hline males $\ldots \ldots \ldots \ldots$ & 14 & $148.5-156.3$ & 2.75 & 0.76 & $151.5 \pm 1.6$ \\
\hline females $\ldots \ldots \ldots$ & 18 & $143.0-155.0$ & 3.80 & 0.90 & $148.6 \pm 1.9$ \\
\hline \multicolumn{6}{|l|}{ australis: } \\
\hline $\begin{array}{l}\text { males } \ldots \ldots \ldots \ldots \ldots \\
\text { females } \\
\ldots \ldots \ldots \ldots\end{array}$ & 10 & $\begin{array}{l}154.0-161.0 \\
150.8-158.2\end{array}$ & $\begin{array}{l}2.08 \\
2.59\end{array}$ & $\begin{array}{l}0.66 \\
0.78\end{array}$ & $\begin{array}{l}158.5 \pm 1.5 \\
154.1+1.7\end{array}$ \\
\hline \multicolumn{6}{|l|}{ grandis: } \\
\hline males .. & 10 & $166.0-175.0$ & 2.90 & 0.92 & $172.0 \pm 2.1$ \\
\hline \multicolumn{6}{|l|}{ monticola: } \\
\hline males $\ldots$ & 44 & $161.3-177.0$ & 3.41 & 0.51 & $167.2 \pm 1.0$ \\
\hline females $\ldots \ldots \ldots$. & 22 & $156.0-171.0$ & 4.12 & 0.85 & $162.8 \pm 1.8$ \\
\hline \multicolumn{6}{|l|}{ alticola: } \\
\hline males $\ldots \ldots \ldots \ldots$ & 8 & $164.5-173.0$ & 2.70 & 0.95 & $167.9 \pm 2.3$ \\
\hline females $\quad \ldots \ldots \ldots$ & 6 & $153.0-162.0$ & 3.83 & 1.56 & $156.7 \pm 4.0$ \\
\hline \multicolumn{6}{|l|}{ mearnsi: } \\
\hline $\begin{array}{l}\text { males } \\
\text { females }\end{array}$ & 38 & $155.0-170.4$ & 3.08 & 0.50 & $161.6 \pm 1.0$ \\
\hline $\begin{array}{r}\text { females } \\
\text { palustris: }\end{array}$ & 27 & $148.0-164.0$ & 8.65 & 0.70 & $157.9 \pm 1.4$ \\
\hline palustris: & 22 & $158.0-169.0$ & 2.74 & 0.58 & $163.2+1.2$ \\
\hline females .. & 20 & $153.5-166.0$ & 0.74 & 0.74 & $159.5 \pm 1.6$ \\
\hline \multicolumn{6}{|l|}{ insularis: } \\
\hline $\begin{array}{l}\text { males } \\
\text { females }\end{array} \ldots \ldots \ldots \ldots$ & 9 & $168.0-176.0$ & 4.33 & 1.44 & $170.3 \pm 3.3$ \\
\hline \multicolumn{6}{|l|}{ collina: } \\
\hline males $\ldots \ldots \ldots \ldots$ & 52 & $158.0-169.9$ & 2.38 & 0.33 & $162.6 \pm 0.7$ \\
\hline females $\ldots \ldots \ldots$ & 22 & $151.0-165.6$ & 3.65 & 0.78 & $157.4 \pm 1.6$ \\
\hline \multicolumn{6}{|l|}{ panamensis: } \\
\hline \multicolumn{6}{|l|}{$\underset{\text { females }}{\text { males }} \ldots \ldots \ldots \ldots$} \\
\hline \multirow{2}{*}{\multicolumn{6}{|c|}{$\begin{array}{l}\text { meloda: } \\
\text { males } \ldots \ldots \ldots \ldots\end{array}$}} \\
\hline & 11 & $164.0-175.5$ & 4.14 & 1.25 & $168.3 \pm 2.8$ \\
\hline females $\quad \ldots \ldots \ldots$ & 10 & $159.4-169.0$ & 3.86 & 1.22 & $164.5 \pm 2.8$ \\
\hline \multicolumn{6}{|l|}{ Tail measurements: } \\
\hline \multicolumn{6}{|l|}{ asiatica: } \\
\hline males $\cdots$ & 32 & $100.7-115.0$ & 3.30 & 0.58 & $108.8 \pm 1.2$ \\
\hline \multirow{2}{*}{\multicolumn{6}{|c|}{ peninsulae: }} \\
\hline & 14 & & 2.72 & 0.72 & \\
\hline females $\ldots$. & 18 & $98.0-104.0$ & 3.22 & 0.76 & $99.6 \pm 1.6$ \\
\hline \multicolumn{6}{|l|}{ australis: } \\
\hline males $\ldots \ldots \ldots \ldots$ & 10 & $108.0-114.0$ & 2.43 & 0.77 & $111.3 \pm 1.7$ \\
\hline females $\ldots$ & 11 & $108.0-112.0$ & 2.29 & 0.69 & $106.2 \pm 1.5$ \\
\hline \multicolumn{6}{|l|}{ grandis: } \\
\hline males $\ldots .$. & 9 & $120.5-133.0$ & 3.60 & 1.2 & $126.6 \pm 2.8$ \\
\hline females & 5 & $112.9-121.3$ & $\mathbf{3 . 8 7}$ & 1.7 & $116.5 \pm 4.7$ \\
\hline \multicolumn{6}{|l|}{ monticola: } \\
\hline $\begin{array}{l}\text { males } \cdots \\
\text { females } \cdots \text {. }\end{array}$ & $\begin{array}{l}44 \\
22\end{array}$ & $\begin{array}{l}114.0-127.5 \\
11.0-124.4\end{array}$ & $\begin{array}{l}3.52 \\
3.67\end{array}$ & $\begin{array}{l}0.55 \\
0.71\end{array}$ & $120.4 \pm 1.1$ \\
\hline \multicolumn{6}{|l|}{ alticola: } \\
\hline males. & 8 & $116.6-129.5$ & 3.89 & 1.87 & $122.0 \pm 3.3$ \\
\hline females $\ldots .$. & 6 & $104.0-113.3$ & 3.58 & 1.46 & $109.9 \pm 3.8$ \\
\hline
\end{tabular}


TABLE.-Measurements of 12 subspecies of white-winged doves-Continued [In millimeters]

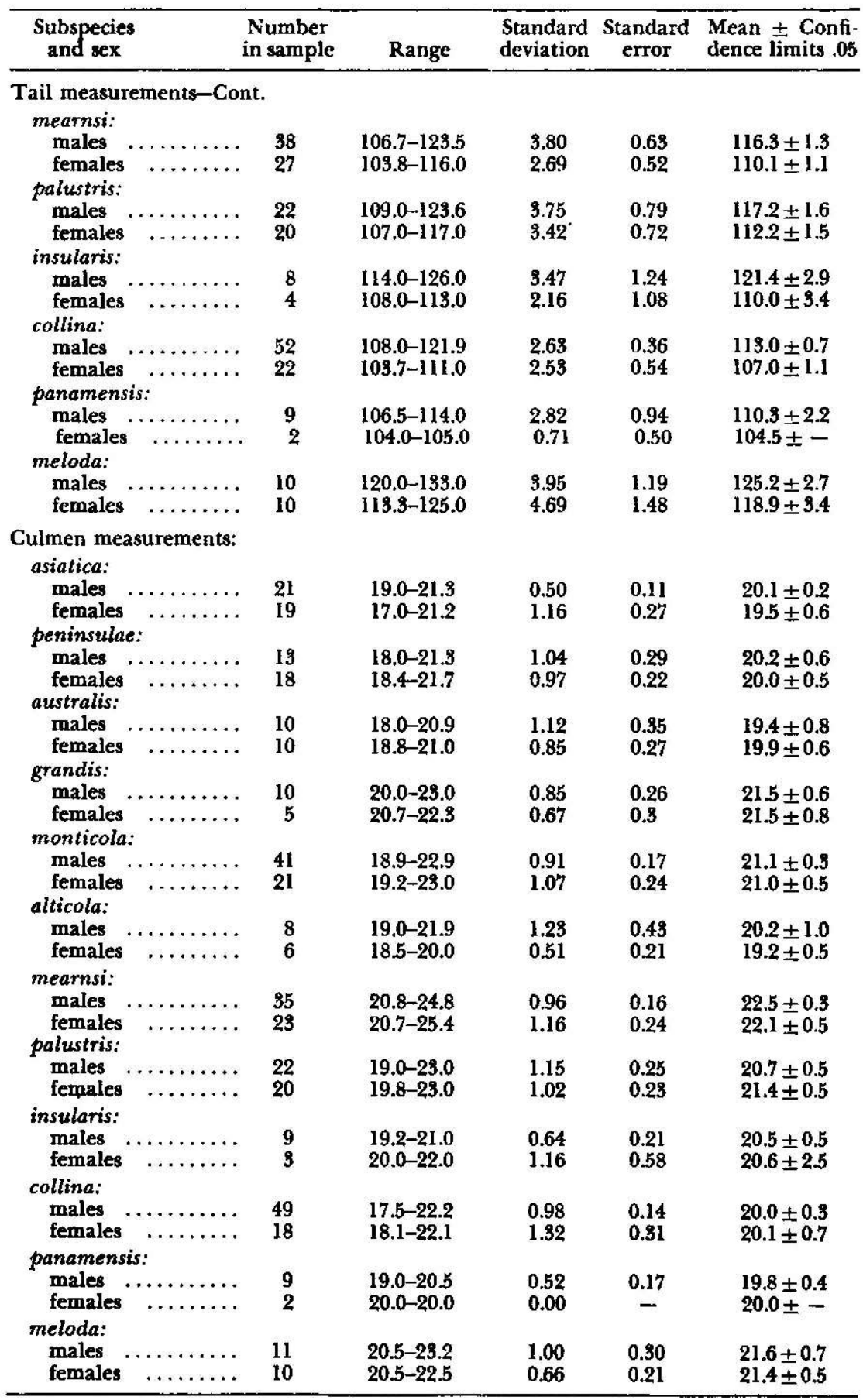




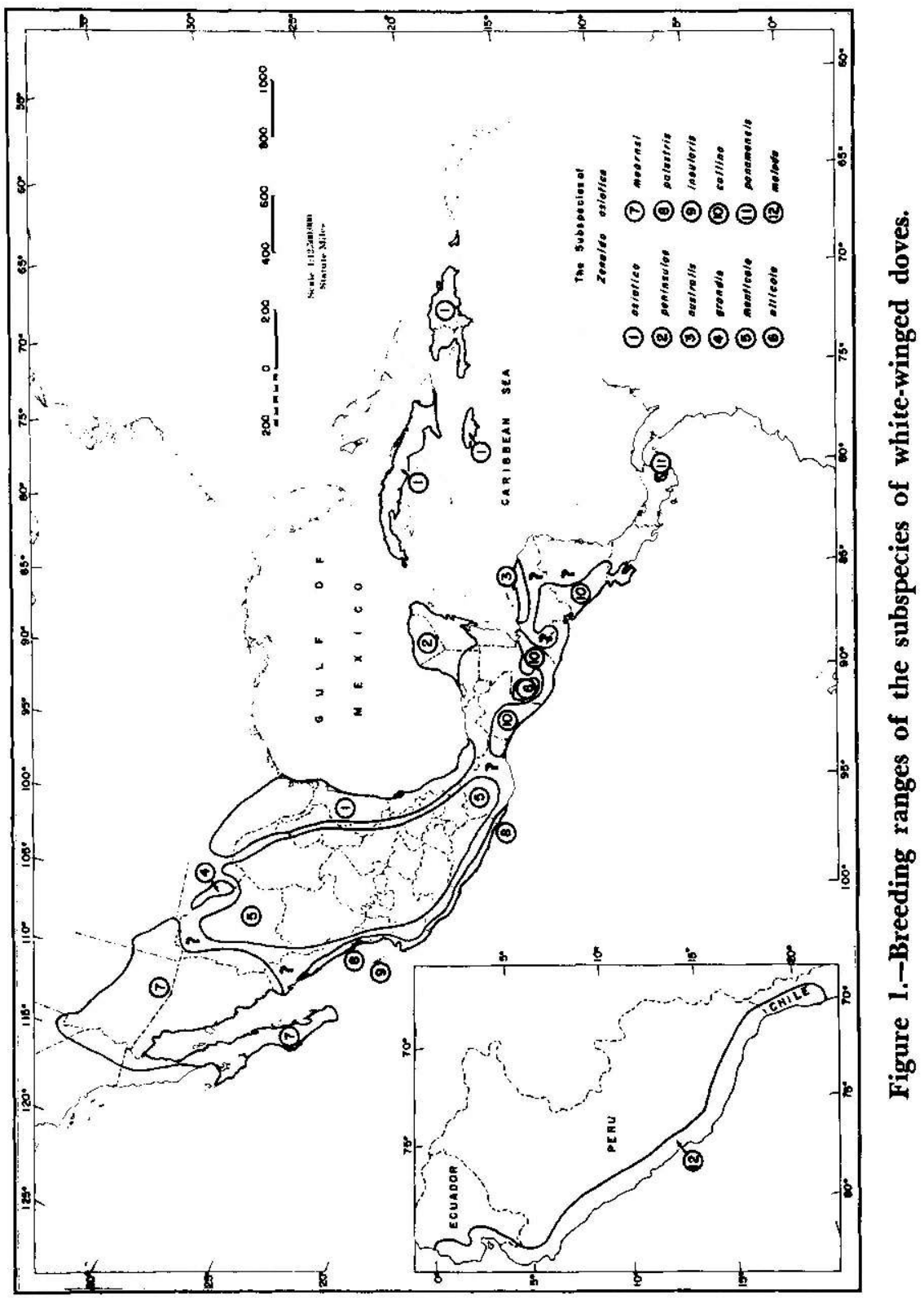




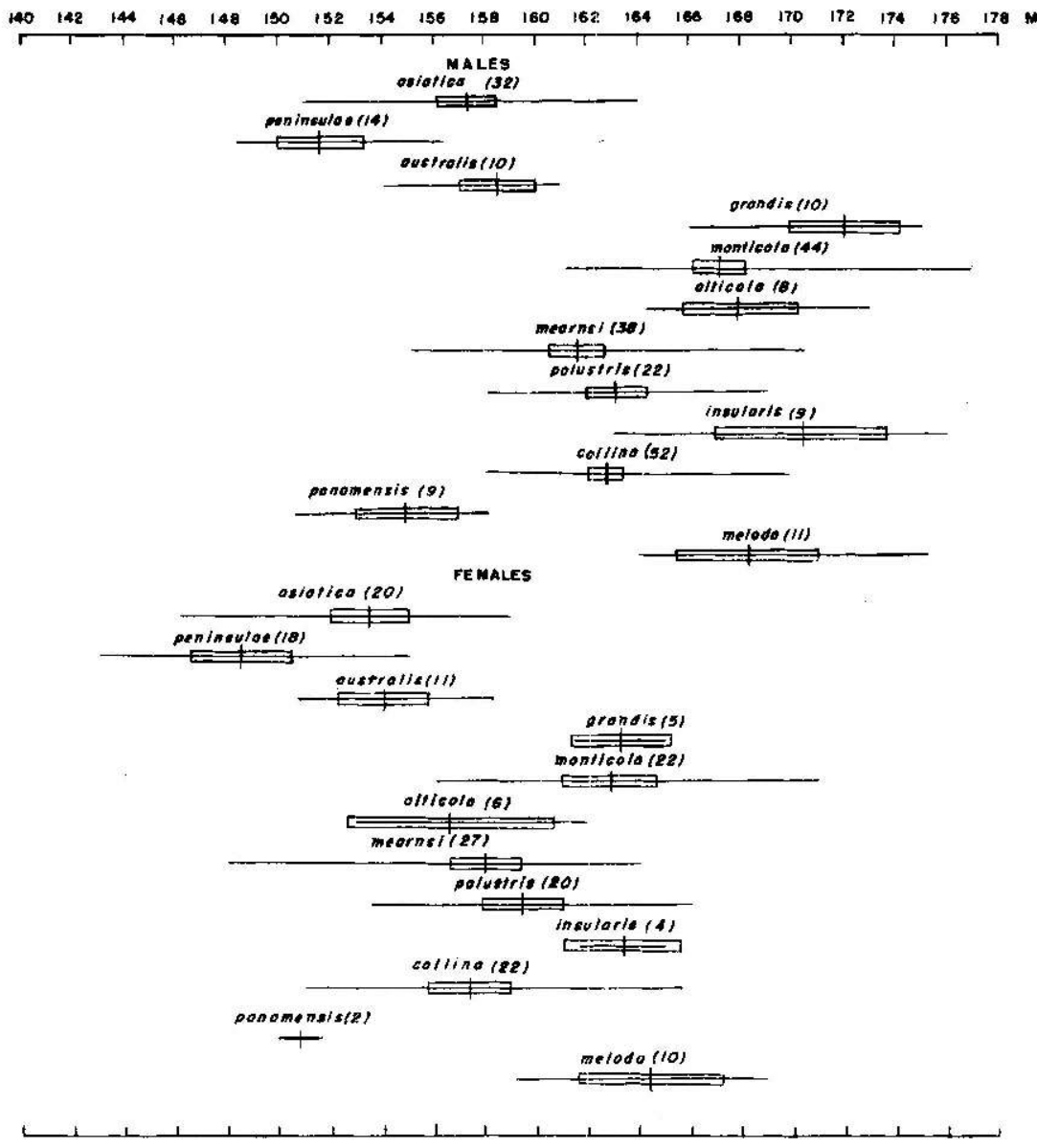

Figure 2.-Statistical comparison of wing measurements of subspecies of white-winged doves.

The present studies indicate that asiatica does not occur as a breeder anywhere on the mainland south of the Isthmus of Tehuantepec, and mearnsi may not breed south of northern Sinaloa.

Morphological differences between populations are not great, and in several races the general trends do not conform to the classical rules of morphological variation correlated with climate. In general, long-winged birds are characteristic of the higher altitudes and more temperate areas, and short-winged birds are typical of the tropical lowlands of the Gulf and Caribbean. However, some of the subspecies having the longest wings and tails are those in tropical lowlands of some Pacific coastal localities from México south to northern Chile. 


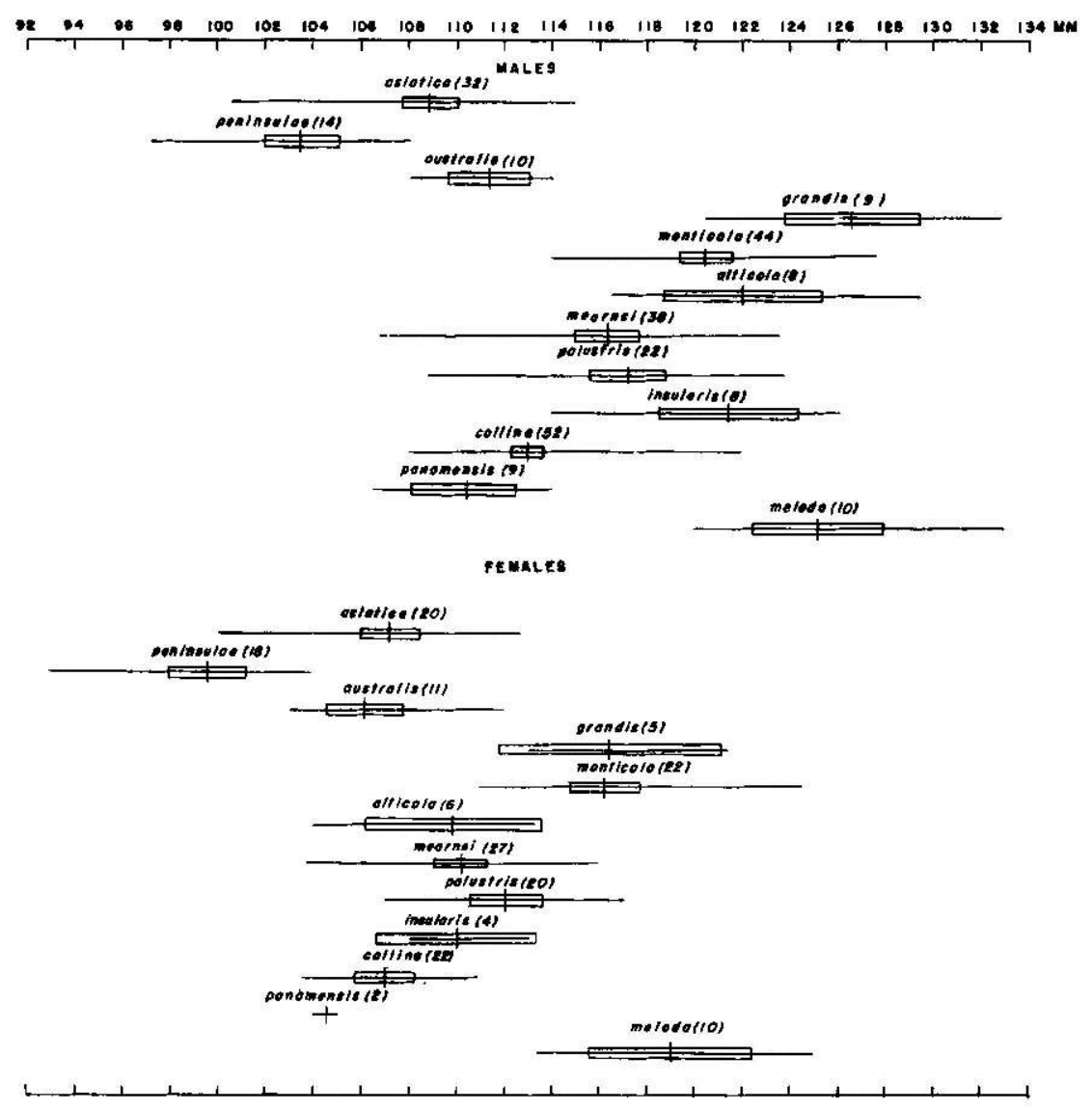

Figure 3.-Statistical comparison of tail measurements of subspecies of white-winged doves.

The various subspecies of white-winged doves do not seem to follow Allen's rules in terms of bill length. All of the races in the hottest year-round habitats, in the tropical lowlands of Central America, and on the Pacific coast of México have short bills. The race with the longest bill is mearnsi, yet its Arizona range is at the greatest latitude of any of the whitewings. Although Arizona desert summers are hot, the more tropical habitats in Latin America are hotter.

The subspecies of whitewings show more agreement with Bergman's rule, but there are exceptions. The largest birds in body size are those in the highlands of México and Central America. They live at 


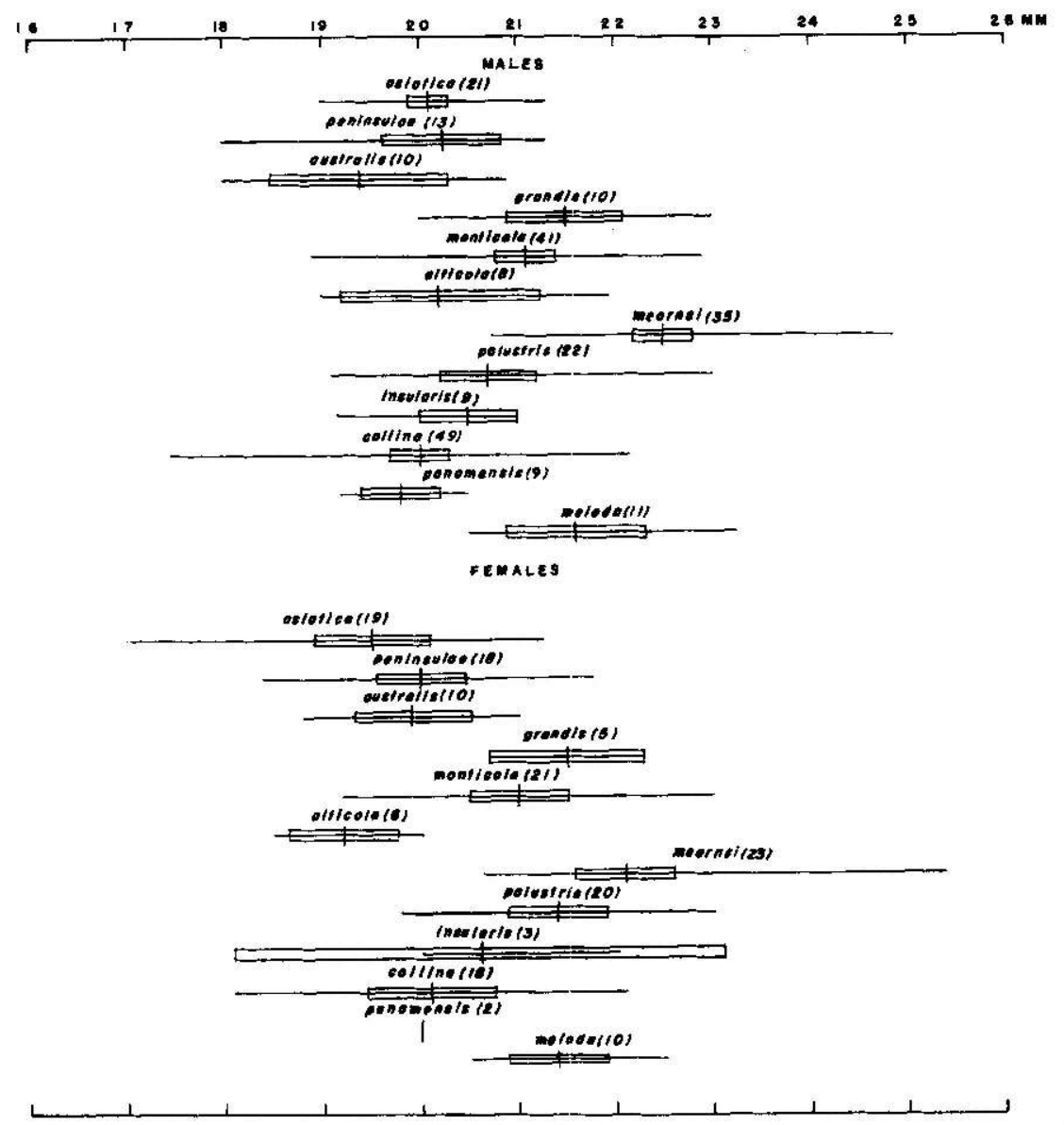

Figure 4.-Statistical comparison of culmen measurements of subspecies of white-winged doves.

higher altitudes where the climate is cooler, but meloda, which also is large, lives in Pacific coastal and piedmont areas of tropical western South America. The climate of the range of meloda is modified somewhat by the proximity of the Humboldt Current. The smallest whitewings in body size are those in the hot, tropical lowlands of Yucatán and Panamá.

In conformance with Gloger's rule, dark pigmentation appears to be associated with the more humid habitats and paler hues with the more arid areas. The darkest are those of the wooded highlands of Guatemala and of the mangtove swamps of the Pacific lowlands of México from southern Sinaloa to Guerrero. The palest are those of 
the deserts of Arizona, Baja California, the highlands of México, and the Pacific coast of South America, especially if breeding specimens are compared. The summer (breeding) plumage shows the greatest contrast between some of the subspecies as birds of arid, rocky habitats show much more fading and wear of plumage than those in more moist woodlands. The plumage of most white-winged doves is darkest and richest in color when in fresh condition after the postnuptial molt. Combinations of these environmentally related characters of dimensions and plumage color are the basis for the differences found in the several races described in this paper.

\section{SUMMARY}

In a study of the distribution and taxonomy of the white-winged dove, Zenaida asiatica, it was found that the subspecies $Z$. a. asiatica of Texas and northeastern México and Z. a. mearnsi of Arizona are strongly migratory. The former winters chiefly in Central America and the latter in western México. With the clarification of their ranges and the study of breeding populations in México and Central America it became apparent that several undescribed races were resident in these countries, Systematic collecting in many localities, the review of museum specimens, and field studies of ecological differences among populations indicated the presence of at least seven undescribed subspecies which are described in this paper.

These subspecies are $Z$. a. peninsulae of the Yucatán peninsula, $Z$. a. grandis of central western Texas, Z. a. monticola of the Mexican highlands, $Z$. $a$. palustris of the central and southern Pacific coastal plain of México, $Z$. a. insularis of the Tres Marías Islands, Nayarit, México, Z. a. collina of Central America, chiefly on the Pacific piedmont and coastal plain from Chiapas, México, to Costa Rica, and Z. $a$. panamensis of the northeast coast of the Azuero peninsula, Panamá. Measurements of specimens, with figures presenting a statistical analysis of these measurements, are given, together with a map showing the breeding ranges. 


\section{LITERATURE GITED}

Bond, JAmEs, and R. M. de Schautnsee.

1944. Results of the Fifth George Vanderbilt Expedition. The Birds. Academy of Natural Sciences of Philadelphia, Monograph 6, p. 7-56.

Carriker, M. A., Jr.

1910. An annotated list of the birds of Costa Rica including Cocos Island.

Carnegie Institute, Annals of the Carnegie Museum, Vol. 6, p. 314-915.

Chapman, F. M.

1896. Notes on birds observed in Yucatan. American Museum of Natural History,

Bulletin 8, p. 271-290.

Cole, Leon J.

1906. Aves from Yucatan. Harvard University, Museum of Comparative Zoology, Bulletin 50, p. 109-146.

Dickey, Donald R., and A. J. van Rossem.

1938. The birds of El Salvador. Field Museum of Natural History, Zoological Series 23, Publication No. 406. 609 p.

Friedmann, Herbert, Ludlow Griscom, and Robert T. Moore.

1950. Distributional check.]ist of the birds of Mexico, Part 1. Cooper Ornithological Club, Pacific Coast Avifauna No. 29. 202 p.

Grant, P. R.

1965. A systematic study of the terrestrial birds of the Tres Marias Islands, Mexico. Yale University, Peabody Museum of Natural History, Postilla, No. 90. $106 \mathrm{p}$.

Griscom, LudLow.

1932. The distribution of bird-life in Guatemala. American Museum of Natural History, Bulletin 64. 425 p.

Hellmayr, C. E., and B. Conover.

1942. Catalogue of birds of the Americas. Field Museum of Natural History, Zoological Series 13, Publication No. 514. 636 p.

LAWRENCE, Georce N.

1874. Birds of western and northwestern Mexico, based upon collections made by Col. A. J. Grayson, Capt. J. Xantus and Ferd. Bischoff, now in the Museum of the Smithsonian Inst. at Washington, D. C. Boston Society of Natural History, Memoirs, Vol. 2, No. 30, p. 265-319.

MAYR, E., E. G. LINSLEY, and R. L. USINGER.

1953. Methods and principles of systematic zoology. McGraw-Hill, New York. 797 p.

Mcleltan, M. E.

1927. Notes on the birds of Sinaloa and Nayarit, Mexico, in the fall of 1925.

California Academy of Science, Proceedings, Vol. 16, No. 1, p. 1-51.

NeLson, E. W.

1899. Birds of the Tres Marias Islands, western Mexico. U. S. Biological Survey, North American Fauna, No. 14, p. 7-62.

Paynter, Raymond A., Jr.

1955. The ornithogeography of the Yucatan Peninsula. Yale University, Peabody Museum of Natural History, Bulletin 9. 347 p.

Peters, James L.

1913. List of birds collected in the Territory of Quintana Roo. Auk, Vol, 30, p. $367-380$.

1937. Check-list of the birds of the world. Harvard University Press, Cambridge. Vol. 3, 311 p. 
Pitelka, Frank A.

1948. Notes on the distribution and taxonomy of Mexican game birds. Condor, Vol. 50, p. 12I-122.

RIDGWAY, ROBERT.

1912. Color standards and color nomenclature. Published by the author, Washington, D. C., 43 p., 58 color plates.

1915. Descriptions of some new forms of American cuckoos, parrots, and pigeons. Biological Society of Washington, Proceedings, Vol. 28, p. 105-107.

1916. Birds of North and Middle America. U. S. National Museum Bulletin 50, Part 7. 543 p.

Salvin, Osbert.

1889. A list of the birds of the islands of the coast of Yucatan and of the Bay of Honduras.. Ibis, Vol. 31, p. 377. and F. D. Godman.

1902. Biologia Centrali-Americana. Aves, Vol. 3, p. 245-247.

SAUnders, George B.

1951. A new white-winged dove from Guatemala. Biological Society of Washington, Proceedings, Vol. 64, P. 83-87.

1959. La paloma de alas blancas en las Americas. Memoria de la Segunda Convencion Nacional Forestal, Departamento de Divulgacion y Propaganda de la Subsecretaria de Recursos Forestales, Mexico, D. F., 1959, p. 414-422.

1962. The white-winged doves of the Americas. U. S. Fish and Wildlife Service, mimeographed, $10 \mathrm{p}$. (Based on a translation of the paper, "La paloma de alas blancas en las Americas," Memoria de la Segunda Convencion Nacional Forestal, Mexico, 1959.)

C. O. Handery, Jr., and A. D. Holloway.

1950. A fish and wildlife survey of Guatemala. U. S. Fish and Wildlife Service, Special Scientific Report-Wildlife, No. 5. 162 p.

SCHALDACH, W. J., Jr.

1963. The avifauna of Colima and adjacent Jalisco, Mexico. Western Foundation of Vertebrate Zoology, Proceedings, Vol. 1, No. 1. 100 p.

Skutch, Al.exander F.

1964. Life histories of Central American pigeons. Wilson Bulletin, Vol, 76, No. 3, p. 211-247.

Stager, Kenneth $\mathrm{E}$.

1957. The avifauna of the Tres Marias Islands, Mexico. Auk, Vol. 74, No. 4, p. $413-432$.

STORER, ROBERT W.

1961. Two collections of birds from Campeche, Mexico. Occasional Papers of the Museum of Zoology, University of Michigan, No. 621, p. 1-20.

vaN Rossem, A. J.

1947. Comment on certain birds of Baja California, including descriptions of three new races. Biological Society of Washington, Proceedings, Vol. 60, p. 51-56.

Van Tyne, Josselyn, and George M. Sutton.

1937. The birds of Brewster County, Texas. Miscellaneous Publications of the Museum of Zoology, University of Michigan, No. 37, 119 p. 